\title{
FGFR3 NM_000142.4:C.742C>T
}

National Cancer Institute

\section{Source}

National Cancer Institute. FGFR3 NM 000142.4:C.742C>T. NCI Thesaurus. Code C128904.

A nucleotide substitution at position 742 of the coding sequence of the FGFR3 gene where cytosine has been mutated to thymine. 